\title{
Gender diversity, ethnic diversity and employee performance in a South African higher education institution
}

\begin{tabular}{|c|c|}
\hline \multicolumn{2}{|c|}{$\begin{array}{l}\text { Authors: } \\
\text { Simbarashe Zhuwao }{ }^{1} \text { (D) } \\
\text { Hlanganipai Ngirande }^{1} \text { (D) } \\
\text { Wiseman Ndlovu }{ }^{1} \text { (D) } \\
\text { Sam T. Setati }{ }^{2} \text { (D) }\end{array}$} \\
\hline \multicolumn{2}{|c|}{$\begin{array}{l}\text { Affiliations: } \\
{ }^{1} \text { Department of Human } \\
\text { Resource Management and } \\
\text { Labour Relations, University } \\
\text { of Venda, Thohoyandou, } \\
\text { Limpopo, South Africa }\end{array}$} \\
\hline $\begin{array}{l}{ }^{2} \text { Department } \\
\text { Management, } \\
\text { of Limpopo, S } \\
\text { South Africa }\end{array}$ & $\begin{array}{l}\text { fusiness } \\
\text { University } \\
\text { ovenga, }\end{array}$ \\
\hline \multicolumn{2}{|c|}{$\begin{array}{l}\text { Corresponding author: } \\
\text { Hlanganipai Ngirande, } \\
\text { hlanganipai.ngirande@ } \\
\text { univen.ac.za }\end{array}$} \\
\hline \multicolumn{2}{|c|}{$\begin{array}{l}\text { Dates: } \\
\text { Received: } 04 \text { Apr. } 2018 \\
\text { Accepted: } 14 \text { Sept. } 2018 \\
\text { Published: } 14 \text { Mar. } 2019\end{array}$} \\
\hline \multicolumn{2}{|c|}{$\begin{array}{l}\text { How to cite this article: } \\
\text { Zhuwao, S., Ngirande, H., } \\
\text { Ndlovu, W., \& Setati, S.T. } \\
\text { (2019). Gender diversity, } \\
\text { ethnic diversity and } \\
\text { employee performance } \\
\text { in a South African higher } \\
\text { education institution. SA } \\
\text { Journal of Human Resource } \\
\text { Management/SA Tydskrif } \\
\text { vir Menslikehulpbronbestuur, } \\
\text { 17(0), a1061. https://doi.org/ } \\
\text { 10.4102/sajhrm.v17i0.1061 }\end{array}$} \\
\hline \multicolumn{2}{|c|}{$\begin{array}{l}\text { Copyright: } \\
\text { (C) 2019. The Authors } \\
\text { Licensee: AOSIS. This } \\
\text { is licensed under the } \\
\text { Creative Commons } \\
\text { Attribution License. }\end{array}$} \\
\hline \multicolumn{2}{|l|}{ Read online: } \\
\hline 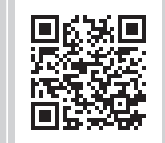 & $\begin{array}{l}\text { Scan this QR } \\
\text { code with your } \\
\text { smart phone or } \\
\text { mobile device } \\
\text { to read online. }\end{array}$ \\
\hline
\end{tabular}

Orientation: Although there has been an improvement in workforce diversity in South Africa, gender and ethnicity issues such as discrimination, prejudice and sexual harassment prevail within organisations. This is because organisational leaders view diversity as a matter of legal compliance instead of as a value addition to organisational growth and profitability. Based on this, it is important for organisations to understand the economic side of diversity and not just be content with having such a workforce.

Research purpose: This study investigated the effects of gender and ethnic diversity on the performance of employees in a selected higher education institution in South Africa.

Motivation of the study: The study was conducted to determine whether gender and ethnic diversity influences the performance of employees in a higher education institution in South Africa. It is believed that by doing so, the study may assist organisational leaders to determine strategies and best practices that will create culture that is inclusive rather than exclusive.

Research approach/design and method: A cross-sectional research design was used. A stratified random sample $(n=258)$ was chosen by dividing employees into homogeneous strata of academic and non-academic employees. A self-administered questionnaire was used to gather data. Pearson product moment correlation and multiple regression analysis were performed.

Main findings: The results show that gender diversity and ethnic diversity are positively and significantly related to employee performance. The study recommends that higher education institutions implement effective diversity management policies and strategies to improve the effectiveness of gender and ethnic diversity towards the performance of employees.

Practical/managerial implications: The study recommends organisations to embrace diversity and not just abide by the affirmative action policies and be satisfied with having such a workforce. To achieve this, effective diversity management programmes such as diversity training and mentoring programmes should be implemented to ensure that all employees are properly trained on diversity issues.

Contribution/value add: First of all, the findings of this study will add to existing knowledge that will aid in the understanding of gender and ethnic diversity in general and its relevance to employee performance, which in turn leads to organisational performance. Furthermore, this study will be an eye opener to organisational leaders and employees as it will help them to begin to see that diversity is a blessing rather than a matter of legal compliance. It will help organisations to see the need for having diversity and confirm that employees can work together despite their differences.

\section{Introduction}

Prior to independence, South African organisations were significantly shaped through social and political discrimination and inequalities of a racial, gender, institutional and spatial nature (Cilliers, 2007). For instance, in the higher education sector, the domain of the academic workforce was characterised by racialisation and gendering, which left higher education institutions (HEIs), as homogeneous entities, dominated by a white and male academic and non-academic workforce (Breetzke \& Hedding, 2016). Post-1994; the new democratically elected government committed itself to institutionalising a new social order in all organisations by implementing diversity initiatives such as the affirmative action policy and Employment Equity Act of 1998. These initiatives declared the need for organisations to respond better to human resources, redress previous 
discriminatory practices and ensure representation and equal opportunities for all (Lumadi, 2011). Owing to these regulatory directives, there has been an improvement in the workforce from a largely homogenous (white and male) workforce to an increasingly multi-ethnic and diverse workforce (Lumadi, 2011). In the higher education sector, the Education Management Information System showed that from 1994 there has been an increment of black people from $19 \%$ to $54 \%$ of the total staff, while women's representation increased from $11 \%$ to $39 \%$ (Department of Higher Education, 2015).

Nevertheless, gender and racial issues such as discrimination, prejudice, stereotypes, abuse and sexual harassment still loom as many black people and women are minimally recognised in organisations (Veldsman, 2013). In addition, tribal discrimination among black people has been rampant, as some still possess the in-group and out-group mentality believed to be a by-product of the apartheid system. Leboho (2017), in his study on workforce diversity, argues that gender and ethnic issues still prevail because most organisational leaders view diversity as a matter of legal compliance instead of as a valuable addition to organisational growth and profitability. If organisations employ women, for instance, simply for the sake of legal compliance, their male counterparts will segregate them, thus leading them to perform at a minimal level (Carter, D'Souza, Simkins, \& Simpson, 2003). Based on this, it is important for organisations to understand the effects of diversity and not just be content with having such a workforce; organisations should make sure that they exploit all the benefits that come from a diversified workforce and ensure that they devise strategies to reduce the negative consequences of diversity. It is to this end that this study seeks to investigate the effects of gender and ethnic diversity on the performance of employees.

\section{Employee performance}

For organisations to become market leaders in this global capitalist market, there is a prime need for them to enhance the performance of employees (Swaratsingh, 2015). Employee performance is referred to as the 'successful completion of tasks by a selected individual and measured by a supervisor or colleague, to pre-defined acceptable standards, while efficiently and effectively utilising available resources within a changing environment' (Tinofirei, 2011, p. 28). According to Osabiya (2015), employee performance may be of benefit to both employees and organisation. Osabiya explained that an employee who performs better has a lesser probability of quitting his or her job. This is based on Vroom's (1964) expectancy theory which suggests that a high-performance appraisal acts as a green light to employees for receiving more recognition, pay raise and promotion in the organisation (Lazaroiu, 2015), hence influencing their decision to commit to their jobs (Linz, Good, \& Busch, 2015). Also, high employee performance could result in increased organisational growth and profitability (Osabiya, 2015). During the industrial revolution period, employee performance was perceived as a variable that was primarily dependent on 'input' aspects, such as financial resources (Beziibwe, 2015). However, recent studies indicate that employee performance is broadly affected by numerous factors and among these factors is workforce diversity (Alm \& Winberg, 2016; Ntim, 2015; Schwab, Werbel, Hofmann, \& Henriques, 2016). Thus, this study will highlight the extent to which employee performance is influenced by gender and ethnic diversity.

\section{Gender diversity}

With the increasing liberalisation of the South African labour force, fostered by various forms of workforce diversity initiatives such as the affirmative action policy, women are also equally participating at all positions in organisations (Carelse, 2013; Msimang, 2010). Although with time women will be offered equal employment opportunities, a wall still exists between employer's perceptions with regards to gender diversity (Fernandez \& Lee, 2016). No country yet has ever completely eradicated gender issues such as discrimination, abuse and sexual harassment (Sharma, 2015). Women are considered less skilled and less qualified for many jobs (Kundu, Kundu, Mor, \& Mor, 2017). Previous studies have suggested that any organisation that considers gender diversity as one of its top priorities stands a chance to retain a talented workforce and increase its performance (Sharma, 2016; Emiko \& Eunmi, 2009; Kochan et al., 2002b).

Various researchers have reviewed the relationship between gender diversity and employee performance. These researchers have different perspectives in terms of whether including women in organisations is beneficial to the organisation or not. Campbell and Minguez-Vera (2008) argued that the presence and acknowledgement of women could positively stimulate their performance and increase organisational performance as they bring additional perspectives to decision-making. Oxelheim (2006) gives examples of additional perspectives that women bring such as enhanced innovation capability, better global market insight and greater awareness of diverse customer needs. However, some researchers stated that the presence of women in organisations might not be of benefit, particularly if legal, political and societal demands for gender equality influence their appointment.

Previous empirical studies also produced mixed results. Most empirical studies conducted in the last decade focused on large organisations in Europe and the United Stated (US). Focusing on large firms in the US, Erhardt, Shrader and Werbel (2003) found that gender diversity was positively related to employee and organisational performance. Another study by Adler (2001) in the US found that organisations that had a good reputation for employing and promoting women had the strongest rates of productivity and profitability and thus concluded that the presence of women in organisations positively correlates with increased employee and organisational productivity. In contrary to these findings, Dobbin and Jung (2012), in their study conducted in 120 financial firms in the US, concluded that 
gender diversity has no effect on employee performance and organisational performance. Similarly, Rose (2007) in his study conducted in Danish firms found no significant link between gender diversity and employee performance. In Spanish organisations, Gallego, Garcia and Rodriguez (2010) also found that gender diversity was not significantly related to employee performance. Given the contrary results, this study further investigates whether gender diversity correlates with employee performance in a higher education institution. Therefore, from the aforementioned literature, the present study hypothesises that there is a relationship between gender diversity and employee performance.

\section{Ethnic diversity}

Ethnicity is referred to as the tribalistic grouping of people (Makokolo, 2005). It designates diversity in religion, language, race and culture (Maingi, 2015). Globalisation and the implementation of workforce diversity initiatives such as affirmative action measures have played a significant role in influencing the adoption of ethnic diversity. Because of its benefits, ethnic diversity has emerged as an economic driver in global business. According to Dastane and Eshegbe (2015), highly ethnically diverse organisations are in a better position to be creative and innovative (Dastane \& Eshegbe, 2015). However, Marx, Pons and Suri (2016) point out that for organisations to benefit from ethnic diversity, managers should have the knowledge and skills to manage diversity because it also comes with detrimental effects if not managed. According to the social identity and self-categorisation theory, when a workforce is ethnically diverse, it may result in psychological processes such as in-group liking, in-group attraction and, worst, in-group favouritism (Tajfel \& Turner, 1986). The result of this may bring behavioural change to employees such that group members may only choose to favour members who belong to their ethnic background. This may also result in negative outcomes, for example, poor communication, less cooperation and less cohesiveness (Ekot, 2017). Furthermore, this may, to a greater extent, lead to conflicts, high turnover intention and minimal job satisfaction and performance (Oerlemans, Peeters, \& Schaufeli, 2001).

Various empirical studies yield mixed results on the relationship between ethnic diversity and employee performance. Using a sample of 400 employees from Malaysian organisations, Weiliang, Mun, Fong and Yuan (2011) found that there was a significant relationship between ethnic diversity and employee performance. Similarly, Earley and Mosakowski (2000) found that ethnic diversity affected employee performance. Also, in the US federal agencies, Pitts (2009) found that ethnic diversity groups in the organisations influenced job performance outcomes. On a different note, in Singapore manufacturing organisations, Selvaraj (2015) found no significant relationship between gender and employee performance. Mugge (2015) also found no link between ethnic diversity and employee performance in a study conducted in research and development organisations in Netherlands. These studies show varied empirical results obtained in different environments and settings. Given these mixed results, this study further investigates the relationship between ethnic diversity and employee performance in a higher education institution. From the aforementioned literature, the present study hypothesises that there is a relationship between ethnic diversity and employee performance.

\section{Research problem}

Although there has been an improvement in workforce diversity in South African organisations, gender and ethnicity issues like discrimination, prejudice and sexual harassment prevail within organisations. This is because organisational leaders view diversity as a matter of legal compliance, instead of as a value addition to organisational growth and profitability (Leboho, 2017). As stated in the introduction, it is important for organisational leaders to understand the effects of diversity in their organisations, to be able to grasp its benefits and to ensure that they devise strategies to reduce the negative consequences of diversity. It is to this end that this study seeks to investigate the effects of gender and ethnic diversity on employee performance.

Furthermore, based on the theoretical and empirical findings, studies conducted on the effects of gender and ethnic diversity on employee performance have yielded contradictory results. Furthermore, these studies were conducted in the European and North American contexts (Campbell \& Minguez-Vera, 2008; Oxelheim, 2006; Rose, 2007). Therefore, this study builds upon this literature gap by exploring the effects of gender and ethnic diversity on employee performance in an HEI in South Africa.

\section{Study objectives}

The objectives of the study are as follows:

- to determine whether there is a relationship between gender diversity and employee performance

- to determine whether there is a relationship between ethnic diversity and employee performance

- to determine which independent variable between gender and ethnic diversity contributes most to the variation of employee performance.

In light of the aforementioned literature, research problem and objectives, Figure 1 demonstrates the conceptual model with regard to determining whether gender diversity and ethnic diversity influence employee performance.

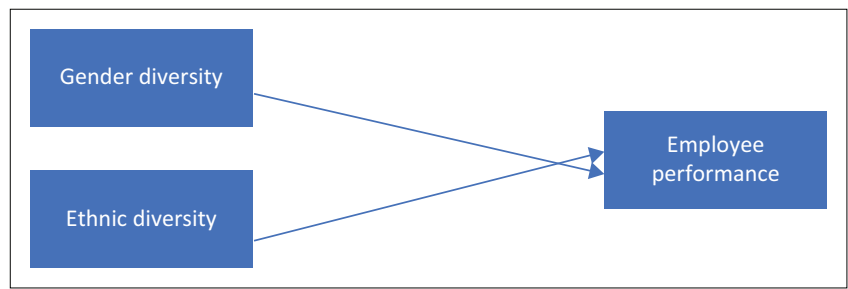

FIGURE 1: The relationship between gender diversity, ethnicity diversity and employee performance. 


\section{Study methodology}

The study adopted a quantitative research approach in the form of a cross-sectional research design. The total population size was $800(N=800)$ staff members who represented both the academic and non-academic workforce, and these formed the target population. A stratified random sampling technique was used to divide staff members into a homogeneous stratum of academic and non-academic employees. To determine the sample size from each stratum, the researcher used Krejcie and Morgan's (1970) method of calculating sample size. Based on Krejcie and Morgan's (1970) method, the minimum recommended sample size for the University of Venda is 267 . To meet the recommended sample size, a total of 300 questionnaires were issued and 258 were filled and returned, thus representing an $86 \%$ response rate.

\section{Measuring instruments}

Elsaid's (2012) 10-item workforce diversity questionnaire was used to measure the perceptions of employees on gender and ethnic diversity. The questionnaire was scored on a five-point Likert scale ranging from 1 (strongly disagree) to 5 (strongly agree). A sample question is: 'There is equal opportunity for career growth and advancement for women in my organization'. The reliability of this scale was considered acceptable as indicated by a Cronbach alpha coefficient of 0.70 in a population of 300 middle managers at the Egyptian pharmaceutical industry (Elsaid, 2012).

Selvaraj's (2015) 10-item employee performance questionnaire was used to assess the performance level of employees. It was scored on a five-point Likert scale ranging from 1 (strongly disagree) to 5 (strongly agree). A sample question is 'I intentionally expend a great deal of effort in carrying out my $\mathrm{job}^{\prime}$. The reliability of this scale was considered satisfactory as shown by a Cronbach alpha coefficient of 0.84 in a population of 316 employees in Singapore organisations (Selvaraj, 2015).

\section{Administering of the questionnaire}

The questionnaire was self-administered. Permission was requested from the human resource management office of the institution to distribute the questionnaires. The anonymity and confidentiality of the information to be obtained from the questionnaires was emphasised to the human resource department and to the respondents in the cover letter. Also, participants were informed of their rights regarding participation in the study and were given an opportunity to give their consent expressly.

\section{Data analysis}

Data were analysed through the use of the Statistical Package for Social Sciences (SPSS) program version 23 (IBM-SPSS

TABLE 1: The stratification of the university employees.

\begin{tabular}{lcc}
\hline Category & Frequency $(f)$ & Percentage of employees \\
\hline Academic & 351 & 43.8 \\
Non-academic & 449 & 56.1 \\
\hline
\end{tabular}

Source: IBM-SPSS Institute. (2013). SPSS 12.0 for Windows. Chicago, IL: SPSS.
Institute, 2013). Descriptive statistics (frequencies and percentages) were used to describe the data in a summary form. Pearson correlation analysis was carried out to test the relationship between the independent variable (gender diversity and ethnic diversity) and the dependent variable (employee performance). Furthermore, the multiple regression analysis was carried out to test which independent variable has the most significant influence on employee performance. The level of statistical significance was measured at $p<0.01$.

\section{Reliability analysis}

To test the internal consistency of the items, a reliability analysis was performed. Table 2 shows that gender diversity was measured using five items and a coefficient alpha of 0.71 was obtained, while ethnic diversity was measured with seven items and a coefficient alpha of 0.78 was obtained. Lastly, employee performance was measured with 10 items and a coefficient alpha of 0.83 was obtained. Above all, the reliability scores were generally acceptable as they were above 0.70 (Andrew, Arora, Bilmes, \& Livescu, 2013).

\section{Factor analysis}

Because of the use of existing questionnaires that have been applied in various situations and settings, factors of these variables are already known. Given this, it was perceived in this study that the systematic interdependence of the latent factors of commonality was known and therefore, in this regard, factor analysis was not performed in this study.

\section{Study results Descriptive statistics}

Table 3 describes the demographic profile of the respondents. As shown in the table, females were the largest group (141 [54.7\%]). In terms of ethnicity, the Venda ethnic group was the largest (76 [29.5\%]), followed by the Tsonga (46 [17.8\%]).

TABLE 2: Reliability of gender diversity, ethnic diversity and employee performance.

\begin{tabular}{llccc}
\hline Number & Construct & Coefficient alpha $(\boldsymbol{r})$ & Items & Reliability level \\
\hline 1 & Gender diversity & 0.71 & 5 & Good \\
2 & Ethnic diversity & 0.78 & 7 & Good \\
3 & Employee performance & 0.83 & 10 & Good \\
\hline
\end{tabular}

Source: IBM-SPSS Institute. (2013). SPSS 12.0 for Windows. Chicago, IL: SPSS.

TABLE 3: Demographic profile of the respondents.

\begin{tabular}{llcc}
\hline Item & Category & Frequency $(f)$ & Percentage \\
\hline Gender & Male & 117 & 45.3 \\
& Female & 141 & 54.7 \\
Ethnicity & Zulu & 20 & 7.8 \\
& Swati & 18 & 7.0 \\
& Venda & 76 & 29.5 \\
& Pedi & 38 & 14.7 \\
& English & 15 & 5.8 \\
& Africana & 5 & 1.9 \\
& Tsonga & 46 & 17.8 \\
& Others & 40 & 15.5 \\
\hline
\end{tabular}

Source: IBM-SPSS Institute. (2013). SPSS 12.0 for Windows. Chicago, IL: SPSS. 
Table 4 shows the percentage distribution of the respondents on gender issues at the University of Venda. As shown in the table, $11.1 \%$ of the respondents disagreed that there were equal opportunities for career growth and advancement for women in the organisations while $49.4 \%$ agreed. For the statement, 'the opposite gender can perform well and enjoy working with them', $4.9 \%$ of our respondents disagreed, $16.0 \%$ of our respondents were neutral and $40.7 \%$ agreed with the statement. For the statement, 'employees have not been discriminated [against] by employer during promotional opportunities based on gender', the percentage distribution shows that $6.2 \%$ of our respondents disagreed with the statement, $12.3 \%$ were neutral and $43.2 \%$ agreed. For the statement, 'dissimilarity in gender leads to poor performance', $6.2 \%$ disagreed with the statement, $12.3 \%$ were neutral and $43.2 \%$ agreed with the statement. The frequency distribution of the respondents to the statement 'a workforce of the same gender can easily form working groups' indicates that $19.8 \%$ of our respondents strongly disagreed, $22.2 \%$ of the respondents were neutral and $49.4 \%$ agreed with the statement.

Table 5 shows the percentage distribution of the respondents on ethnic issues at the university. For the statement 'My ethnic background and my working with colleagues from different ethnic backgrounds influence my ability to carry out my task well', $23.5 \%$ of our respondents strongly disagreed, $4.9 \%$ of our respondents were neutral and $43.2 \%$ agreed. For the statement 'Different languages used to communicate in the workplace do not create conflict among employees', $23.5 \%$ of our respondents disagreed, $6.2 \%$ were neutral and $56.8 \%$ agreed. For the statement 'I co-operate well with my colleagues of different ethnicity', $7.4 \%$ of our respondents disagreed, $1.2 \%$ of our respondents were neutral and $40.7 \%$ agreed. For the statement 'I develop low self-esteem in the workplace due to my ethnic background' , $45.7 \%$ of our respondents disagreed, $11.1 \%$ of our respondents were neutral and $17.3 \%$ agreed. For the statement 'The language differences among employees affect group formation and cohesion', the percentage distribution of the responses indicates that $28.4 \%$ of our respondents disagreed, $18.5 \%$ of our respondents were neutral and $32.1 \%$ agreed with the statement.

\section{Inferential statistics}

Table 6 describes the results of the relationship between gender diversity and employee performance, showing that there is a positive and significant relationship between gender diversity and employee performance $(r=0.274, p=0.000)$.

The relationship between ethnic diversity and employee performance was tested. Based on the results shown in Table 7, there is a positive and significant relationship between ethnic diversity and employee performance $(r=0.277, p=0.000)$.

To determine the extent to which the independent variables explain variation of employee performance, the model summary was computed. The results in Table 8 show that the $R$-square value is 0.719 , thus meaning that gender and ethnic diversity can explain $71.9 \%$ of the dependent variable (employee performance). However, it still leaves out 28.1\% $(100 \%,-71.9 \%)$ unexplained in this research. This implies that there are other additional important variables that have not

\begin{tabular}{lcc}
\multicolumn{3}{l}{ TABLE 6: Correlation between gender diversity and employee performance. } \\
\hline Variable & Gender diversity & Employee performance \\
\hline Gender diversity & 1 & \\
Pearson correlation & - & $0.274^{*}$ \\
Sig. (two-tailed) & & 0.000 \\
Employee performance & - & 1 \\
Pearson correlation & - & - \\
Sig. (two-tailed) & \\
\hline
\end{tabular}

Source: IBM-SPSS Institute. (2013). SPSS 12.0 for Windows. Chicago, IL: SPSS.

*, Correlation is significant at the 0.01 level (two-tailed).

Sig., significance.

TABLE 7: The relationship between ethnic diversity and employee performance. Variable Gender diversity Employee performance

\begin{tabular}{lcc}
\hline Gender diversity & & \\
Pearson correlation & 1 & $0.277^{*}$ \\
Sig. (two-tailed) & - & 0.000
\end{tabular}

Employee performance

Pearson correlation

Sig. (two-tailed)

Source: IBM-SPSS Institute. (2013). SPSS 12.0 for Windows. Chicago, IL: SPSS.

*, Correlation is significant at the 0.01 level (two-tailed).

Sig., Significance.

TABLE 4: Central tendencies measurement: Gender diversity.

\begin{tabular}{|c|c|c|c|c|c|c|}
\hline No. & Question & SD (\%) & $\mathrm{D}(\%)$ & $\mathrm{N}(\%)$ & $A(\%)$ & SA (\%) \\
\hline 1 & Opposite gender can perform well and I enjoy working with them. & 2.5 & 4.9 & 16.0 & 40.7 & 35.8 \\
\hline 2 & Employees have not been discriminated [against] by employer during promotional opportunities based on gender. & 2.5 & 6.2 & 12.3 & 43.2 & 35.8 \\
\hline 3 & Dissimilarity in gender leads to poor employee performance. & 2.5 & 6.2 & 12.3 & 43.2 & 9.9 \\
\hline 4 & Workforce of the same gender can easily form working groups. & 3.7 & 19.8 & 22.2 & 49.4 & 4.9 \\
\hline 5 & There is equal opportunity for career growth and advancement for women in my organisation. & 2.5 & 11.1 & 6.2 & 49.4 & 30.9 \\
\hline
\end{tabular}

Source: IBM-SPSS Institute. (2013). SPSS 12.0 for Windows. Chicago, IL: SPSS.

$\mathrm{SD}$, strongly disagree; D, disagree; N, neutral; A, agree; SA, strongly agree.

TABLE 5: Central tendencies measurement: Ethnic diversity.

\begin{tabular}{|c|c|c|c|c|c|c|}
\hline No. & Question & SD (\%) & $\mathrm{D}(\%)$ & $\mathrm{N}(\%)$ & $A(\%)$ & SA (\%) \\
\hline 1 & Working with colleagues from different ethnic backgrounds influences my decision-making ability. & 13.6 & 23.5 & 4.9 & 43.2 & 13.6 \\
\hline 2 & Different languages used to communicate in the workplace do not create conflict among employees. & 8.6 & 23.5 & 6.2 & 56.8 & 4.9 \\
\hline 3 & I co-operate well with my colleagues of different ethnicity. & 6.2 & 7.4 & 1.2 & 40.7 & 44.4 \\
\hline 4 & The language differences among employees affect group formation and cohesion. & 16.0 & 28.4 & 18.5 & 32.1 & 4.9 \\
\hline 5 & I develop low self-esteem in the workplace due to my ethnic background. & 18.5 & 45.7 & 11.1 & 17.3 & 7.4 \\
\hline
\end{tabular}


TABLE 8: Model summary.

\begin{tabular}{|c|c|c|c|c|c|c|}
\hline \multirow{2}{*}{ Model } & \multirow{2}{*}{$\frac{\boldsymbol{R}}{0.848 \dagger}$} & \multirow{2}{*}{$\begin{array}{c}\boldsymbol{R} \text {-square } \\
0.719\end{array}$} & \multicolumn{2}{|c|}{ Adjusted $R$-square } & \multicolumn{2}{|c|}{ SE of the estimate } \\
\hline & & & & 0.660 & \multicolumn{2}{|c|}{0.319} \\
\hline \multicolumn{7}{|c|}{$\begin{array}{l}\text { Source: IBM-SPSS Institute. (2013). SPSS } 12.0 \text { for Windows. Chicago, IL: SPSS. } \\
\text { SE, standard error. } \\
\dagger \text {. Predictors (constant) - gender diversity and ethnic diversity. }\end{array}$} \\
\hline Model 1 & Sun & of squares & $D f$ & Mean square & $I$ & Sig. \\
\hline Regression & & 1.793 & 2 & 0.4735 & 3.605 & $0.000 \dagger$ \\
\hline Residual & & 6.887 & 54 & 0.1275 & - & - \\
\hline Total & & 8.680 & 56 & - & - & - \\
\hline
\end{tabular}

Source: IBM-SPSS Institute. (2013). SPSS 12.0 for Windows. Chicago, IL: SPSS.

Note: Significant at the 0.01 level.

Note: Significant at the 0.01 level.

$\dagger$, Predictors: (constant) - gender diversity and ethnic diversity.

TABLE 10: Gender diversity and ethnic diversity as predictors of employee performance.

\begin{tabular}{lccccc}
\hline Model 1 & \multicolumn{2}{c}{$\begin{array}{c}\text { Unstandardised } \\
\text { coefficients }\end{array}$} & \multirow{2}{*}{$\begin{array}{c}\text { Standardised } \\
\text { coefficients } \\
\text { (beta) }\end{array}$} & $\boldsymbol{T}$ & Sig. \\
\cline { 2 - 3 } & $\boldsymbol{B}$ & $\mathrm{SE}$ & & & \\
\hline (Constant) & 11.339 & 1.033 & - & 13.898 & 0.000 \\
Gender diversity & 0.798 & 0.124 & 0.214 & 2.528 & 0.000 \\
Ethnic diversity & 0.776 & 0.112 & 0.241 & 3.327 & 0.000 \\
\hline
\end{tabular}

Note: Dependent variable - employee performance

$B$, standard coefficients; $\mathrm{SE}$, standard error; $T$, $T$-Statistic; Sig., significance.

been considered in this study and are important in explaining variation in employee performance.

To examine the statistical significance of the regression model on whether it is a good descriptor for the relationship between the independent variables (gender diversity and ethnic diversity) and the dependent variable (employee performance), Analysis of variance (ANOVA) was performed. Thus, the results in Table 9 show that the model is a good descriptor of the relationship between the independent variables (gender diversity and ethnic diversity) and the dependent variable (employee performance) $(F=3.605$; $p=0.000$ ). This means that the independent variables (gender diversity and ethnic diversity) are significant in explaining variance in the dependent variable (employee performance).

To compare which independent variable between gender diversity and ethnic diversity contributes most to the variation of employee performance, beta standardised coefficients were used. Thus, the results in Table 10 indicate that ethnic diversity contributed most to the variation of employee performance $(\beta=0.241 ; p=0.000)$.

\section{Discussion}

\section{The relationship between gender and employee performance}

From the findings, there is a significant positive relationship between gender diversity and employee performance $(r=0.274, p=0.00)$ at the University of Venda. The findings also showed that gender diversity has a high predictive power on employee performance. From the survey, most of the respondents agreed that the institution does not discriminate when it comes to hiring different genders and that it provides equal opportunities for women with regards to developing their careers. This shows that the management at the University of Venda upholds diversity policies and implements their practices. This study does not support the claim by Arokiasamy (2013) that organisational leaders prefer to hire more male employees than female because it is believed that the males have more capacity to be highly effective than female employees. Based on the result of the data analysed in the hypothesis tested, it is evident that gender diversity has a significant relationship with employee performance. These findings are in conformity with Erhardt (2008) and Alder (2008), who stated that the mix of cognitive abilities of men and women could be the reason for this positive outcome. However, as stated by Leboho (2017), issues such as discrimination and sexual harassment of the opposite gender can result in a negative effect of gender diversity on employee performance. In contrast, organisations that create an inclusive environment for all employees irrespective of gender and create policies that eliminate discrimination from the workplace can benefit from gender diversity (Milliken \& Martins, 1996). A significant relationship between gender diversity and employee performance may also imply that some employees prefer to work with the opposite gender as long as they can do their job in a professional way.

\section{The relationship between ethnic diversity and employee performance}

The results also show that ethnic diversity is positively and significantly related to employee performance $(r=0.277$, $p=0.00)$. This means that ethnic diversity positively affects employee performance at the University of Venda. According to the social identity, social categorisation and similarity attraction theories, when a workforce is ethnically diverse, it could result in psychological processes like in-group liking, in-group attraction, and worst of all, in-group favouritism. This could also bring about many negative outcomes like less communication, less cooperation, less cohesiveness and even conflicts (Tajfel \& Turner, 1986). However, given the results of this study, it seems the management of the institution is committed to managing the ethnic diversity of their workforce in ways that will help the organisation. The majority of the employees agree that they cooperate well with fellow colleagues of different ethnic background, meaning that there is no conflict irrespective of their languages. The finding is consistent with those of Pitts (2009) and Weiliang et al. (2011), who indicated that there is a significant relationship between ethnic diversity and employee performance. According to these studies, in ethnically diverse organisations, the ethnic identities of team members are less salient and, therefore, create less disruption to employee performance - thus explaining why a performance deficit was not evident in this study.

\section{Conclusion}

The literature shows that most studies on the effects of gender and ethnic diversity on employee performance were 
conducted in the European and American contexts (Adler, 2001; Campbell \& Minguez-Vera, 2008; Erhardt, 2008; Oxelheim, 2006). Thus, the study was built upon this gap and conducted in a, HEI in South Africa. The study reveals that gender and ethnic diversity relates positively to employee performance. Ethnic diversity was found to be the variable contributing the most to employee performance. Therefore, it is concluded that employees at the University of Venda acknowledge gender and ethnic diversity as a benefit to them, as they have shown positive perceptions of gender and ethnic diversity. This clearly shows that the management of the institution understand that promoting the inclusion of women and various ethnic groups adds value to the organisational performance.

\section{Recommendations}

As the study results reveal, gender diversity and ethnic diversity positively affect employee performance. This shows that the University of Venda acknowledges and accepts the need to have a diverse workforce. However, not all organisations are conscious of the significance of diversity. It is important for every organisation to embrace diversity and not just abide by the affirmative action policies and be satisfied with having such a workforce; organisations should ensure that they understand and exploit all the benefits that come from diversity and ensure they put strategies in place to minimise the negative consequences that may come from the in-group and out-group mentality. To achieve this, effective diversity management programmes such as diversity training and mentoring programmes should be implemented. The goals and objectives of these programmes must be constantly and clearly stated to all levels of the organisation and as well linked to the overall business goals. The study further recommends that organisations encourage the use of English as the common language in order to accommodate different ethnic groups in the institution. This prevents communication and ethnocentric conflicts, which can be destructive to the performance of employees (Mwatumwa, 2016).

For future research, the researcher recommends that this same study be conducted again but on a wider scope. That is, it should include more HEIs and increase the population size. The study can also be conducted comparatively by studying one organisation in an industry and another organisation. This will provide deeper understanding on diversity issues.

\section{Acknowledgements Competing interests}

The authors declare that they have no financial or personal relationships that may have inappropriately influenced them in writing this article.

\section{Authors' contributions}

Z.S. was the main author of the article and project leader. N.H. was the co-supervisor of the master's work. N. W. made conceptual contributions and subject alignment. S.T.S. was the main supervisor of the master's work.

\section{References}

Adler, R. D. (2008). Women in the executive state correlate to high profile (Manuscript submitted for publication, Pepperdine University).

Alm, M., \& Winberg, J. (2016). How does gender diversity on corporate boards affect the firm financial performance? (Bachelors thesis, University of Gothenburg)

Arokiasamy, A. R. A. (2013). Literature review on workforce diversity, employee performance and organizational goals: A concept paper. Researchers World, $4(4), 58$.

Beziibwe, A. S. (2015). The relationship between workplace diversity and organisational performance (Doctoral dissertation). Uganda: Uganda Technology and Management University.

Breetzke, G. D., \& Hedding, D. W. (2016). The changing racial profile of academic staff at South African Higher Education Institutions (HEls). Africa Education Review, 13(2), 147-164.

Campbell, K., \& Minguez-Vera, A. (2008). Gender diversity in the boardroom and firm financial performance. Journal of Business Ethics, 83(3), 435-451. https://doi. org/10.1007/s10551-007-9630-y

Carelse, K. (2013). Employees' perceptions towards workplace diversity in a financia institution operating in the Western Cape. Masters dissertation, University of the Western Cape.

Carter, D. A., D'Souza, F. P., Simkins, B. J., \& Simpson, W. G. (2003). The diversity corporate board committees and financial performance. SSRN Working Paper Series, Newyork: US.

Cilliers, F. (2007). Towards a systems of Psychodynamic understanding to South African Diversity. Retrieved from http://www.mngt.walato.ac.nz/ejrot/ cmsconference/2007/proceedings/Psychoanalyst/cilliers.pdf

Dastane, O., \& Eshegbe, J. W. (2015). Effect of diversity elements at the workplace: An empirical study. International Journal of Accounting and Business Management, 3(1), 62-69.

Department of Higher Education. (2015). Transformation and restructuring: A new institutional landscape for higher education. Revised Version for 2010/11 2014/15. DHE, Pretoria: South Africa.

Dobbin, F., \& Jung, J. (2012). Corporate board gender diversity and stock performance: The competence gap or institutional investor bias. North Carolina Review, 89(3), 809-839.

Earley, P., \& Mosakowski, E. (2000). Creating hybrid team culture: An empirical test of transnational team functioning. Academy of Management Journal, 43(1), 26-49.

Ekot, C. (2017). The effects of workforce diversity on employee performance in Nigerian banking industry (A study of first bank Nigeria Ltd., Ota Branch). Masters research, Covenant University, Nigeria.

Elsaid, A. M. (2012). The Effects of cross cultural workforce diversity on employee performance in Egyptian pharmaceutical organizations. Business and Management Research, 1(4), 162-180.

Emiko, M., \& Eunmi, C. (2009). Diversity management and the effects on employees' organisational commitment: Evidence from Japan and Korea. Journal of World Business, 44, 31-40. https://doi.org/10.1016/j.jwb.2008.03.018

Erhardt, L. N., Shrader, C. B., \& Werbel, J. D. (2003). Board of director diversity and firm performance corporate governance. An international Review, 11(2), 102-110.

Erhardt, L. N. (2008). Board of director diversity and firm financial performance. Corporate Governance. An International Review, 11(2), 102-110.

Fernandez, S., \& Lee, H. (2016). The transformation of the South African Public Service: Exploring the impact of racial and gender representation on organisational effectiveness. The Journal of Modern African Studies, 54(1), 91-116. https://doi. org/10.1017/S0022278X15000816

Gallego, I., Garcia, I. M., \& Rodriguez, L. (2010). The influence of gender diversity on corporate performance. Revista de Contabilidada-Acounting Review. 13(1), 54-68.

IBM-SPSS Institute. (2013). SPSS 12.0 for Windows. Chicago, IL: SPSS.

Kochan, T., Bezrukova, K., Ely, R. Jackson, D., \& Joshi, A. K. (2002b). The effects of diversity on business performance. Human Resource Management Journal, 42(1), 36-45.

Kochan, T., Bezrukova, K., Ely, R., Jackson, S., Joshi, A., \& Jehn, K. (2002a). The effects of diversity on business performance. Alexandria, VA: Diversity Research Network.

Krejcie, R. V., \& Morgan, D. W. (1970). Determining sample size for research activities. Educational and Psychological Measurement, 30(3), 607-610. https://doi. org/10.1177/001316447003000308

Kundu, S. C., \& Mor, A. (2017). Workforce diversity and organisational performance: A study of IT industry in India. Employee Relations, 39(2), 160-183. https://doi. org/10.1108/ER-06-2015-0114

Lazaroiu, G. (2015). Work motivation and organizational behavior. Contemporary Readings in Law and Social Justice, 7(2), 66.

Leboho, M. (2017). The relationship between gender diversity and corporate profitability: The top 100 companies on the JSE Itd. Masters research, University of Johannesburg, South Africa.

Linz, S., Good, L. K., \& Busch, M. (2015). Promoting worker loyalty: An empirical analysis. International Journal of Manpower, 36(2), 169-191. https://doi.org/ 10.1108/IJM-06-2013-0129 
Lumadi, M. W. (2011). Managing diversity at higher education and training institutions: A daunting task. Journal of Diversity Management, 3(4), 1-10.

Maingi, J. W. (2015). Effect of workforce diversity on employee performance in Kenya: A case of Kenya school of government. Strategic Journal of Business \& Change Management, 2(2), 52-68.

Makokolo, M. (2005). Minority indigenous peoples and ethnic diversity in Kenya London, UK: Minority Rights Group International.

Marx, B., Pons, V., \& Suri, T. (2016). Diversity and team performance in a Kenyan organisation. Harvard Business School, MA.

Milliken, F. J., \& Martins, L. L. (1996). Searching for common threads: Understanding the multiple effects of diversity on occupational groups. Academy of Management Review, 21, 403-433.

Msimang, S. (2010). Affirmative action in the new South Africa: The politics of representation. Law and Equity accessed, 4, 25.

Mugge, L. (2015). Where gender and ethnicity intersect: How Dutch political parties recruit and select candidates. Doctoral research, University of Amsterdam, the Netherlands.

Mwatumwa, A. S. (2016). Effect of workforce diversity on employee work performance: A study of the county government of Mombasa. Masters dissertation, University of Mombasa, Kenya.

Ntim, C. G. (2015). Broad diversity and organisational valuation. Unraveling the effects of ethnicity and gender. Journal of Management \& Governance, 19(1) 167-195.

Oerlemans, W. G., Peeters, M. C., \& Schaufeli, W. B. (2001). Ethnic diversity at work An overview of theories and research. Retrieved from http://www.wilmarschaufeli. $\mathrm{nl} /$ publications/Schaufeli/292.pdf

Osabiya, B. J. (2015). The effect of employee's motivation on organizational performance. Journal of Public Administration and Policy Research, 7(4), 62-75.

Oxelheim, L. (2006). A Nordic perspective of corporate board diversity. Norway: Nordic Innovation Centre.
Pitts, D. (2009). Diversity management, job satisfaction, and performance: Evidence from US federal agencies. Public Administration Review, 69(2), 328-338.

Rose, F. S. (2007). Does female board representation influence firm performance? The Danish evidence, Corporate Governance. An International Review, 15(2), 404-413. https://doi.org/10.1111/j.1467-8683.2007.00570.x

Schwab, A., Werbel, J. D., Hofmann, H., \& Henriques, P. L. (2016). Managerial gender diversity and firm performance: An integration of different theoretical perspectives. Group \& Organization Management, 41(1), 5-31. https://doi.org/10.1177/ 1059601115588641

Selvaraj, P. C. (2015). The effects of work force diversity on employee performance in Singapore organisations. International Journal of Business Administration, 6(2), $17-30$.

Sharma, A. (2015). Managing diversity and equality in the workplace. Cogent Business and Management, 3, 1-14.

Sharma, A. (2016). Managing diversity and equality in the workplace. Cogent Business \& Management, 3(1), 121-136.

Swaratsingh, K. (2015). Enhancing workplace productivity and competitiveness in Trinidad and Tobago through ICT adoption (Doctoral dissertation, Walden University).

Tajfel, H., \& Turner, J. C. (1986). Social identity and intergroup relations. Cambridge University Press.

Tinofirei, C. (2011). The unique factors affecting employee performance in non-profit organisations (Master's dissertation, University of South Africa).

Veldsman, D. M. (2013). Perceptions of diversity management in a public sector. Doctoral dissertation, University of the Western Cape, South Africa.

Weiliang, E. C., Mun, L. S., Fong, T. S., \& Yuan, Y. P. (2011). The effects of workforce diversity towards the employee performance in an organization. Unpublished thesis, University Tunku Adbul Rahman.

Welman, C., Kruger, F., \& Mitchell, B. (2011). Research methodology (3rd edn.). Cape Town, South Africa: Oxford University Press. 